\title{
Genetic analyses of claw health in Norwegian Red cows
}

\author{
C. Ødegård, ${ }^{*} \dagger^{1} M$. Svendsen, $\dagger$ and B. Heringstad ${ }^{*} \dagger$ \\ *Department of Animal and Aquacultural Sciences, Norwegian University of Life Sciences, PO Box 5003, NO-1432 Ås, Norway \\ †Geno Breeding and A. I. Association, PO Box 5003, NO-1432 Ås, Norway
}

\section{ABSTRACT}

The aim of this study was genetic analyses of claw health in Norwegian Red. Claw health status at claw trimming has, since 2004, been recorded in the Norwegian Dairy Herd Recording System. The claw trimmer records whether the cow has normal (healthy) claws or if one or more claw disorders are present. Nine defined claw disorders were recorded: corkscrew claw (CSC), heel horn erosion $(\mathrm{HH})$, dermatitis (DE), sole ulcer (SU), white line disorder (WLD), hemorrhage of sole and white line (HSW), interdigital phlegmon (IDP), lameness (LAME), and acute trauma (AT). Data from 2004 to 2011, with a total of 204,892 claw health records, were analyzed. The disorders were defined as binary traits with 1 record per cow per lactation. Further, 3 groups of claw disorders were analyzed: infectious claw disorders (INFEC, containing HH, DE, and IDP); laminitis-related claw disorders (LAMIN, containing SU, WLD, and HSW); and overall claw disorder. The 9 single traits and the 3 groups were analyzed using univariate threshold sire models. Multivariate threshold models were performed for the 5 most frequent single traits (CSC, HH, DE, SU, and WLD) and for CSC together with the grouped traits INFEC and LAMIN. Posterior mean of heritability of liability ranged from 0.04 to 0.23 , where CSC had the highest heritability. The posterior standard deviations of heritability were low, between 0.01 and 0.03 , except for IDP (0.06). Heritability of liability to INFEC and LAMIN were both 0.11 and for overall claw disorders, the heritability was 0.13 . Posterior means of the genetic correlation among the 5 claw disorders varied between 0.02 and 0.79 , and the genetic correlations between $\mathrm{DE}$ and $\mathrm{HH}$ (0.65) and between WLD and SU (0.79) were highest. Genetic correlation between INFEC and CSC was close to zero (0.06), between LAMIN and CSC it was 0.31, and between LAMIN and INFEC it was 0.24 . The results show that claw disorders are sufficiently heritable for genetic evaluation and inclusion in the breeding scheme. At present, data are scarce with few recorded

Received December 20, 2012.

Accepted July 16, 2013.

${ }^{1}$ Corresponding author: cecilie.odegard@umb.no daughters per sire. Claw trimming records from more herds would therefore be beneficial for routine genetic evaluation of claw health.

Key words: claw disorder, dairy cow, genetic parameter, threshold model

\section{INTRODUCTION}

Claw health has become important in Norway due to the increased use of freestalls (Simensen et al., 2010). The incidence of claw disorders in Norwegian Red treated by veterinarians has increased from 1990 to 2005 (Østerås et al., 2007). Sogstad et al. (2005) found, in a cross-sectional study, that 71.8 and $47.8 \%$ of the cows in freestalls and tiestalls, respectively, had claw lesions. Lameness causes economic losses to the farmer (Enting et al., 1997) because it influences production diseases (Sogstad et al., 2006), fertility (Sogstad et al., 2006; Walker et al., 2008), early culling (Sogstad et al., 2007a), and milk production (Sogstad et al., 2007b). Not all cases of claw disorders show clinical signs, so the number of cows with claw disorders may be higher than the number of lame cows. Environmental factors, such as herd, flooring, and feeding, affect claw disorders (e.g., Bielfeldt et al., 2005; Fjeldaas et al., 2011; Buttchereit et al., 2012). Experience in detecting claw disorders may vary between claw trimmers. Holzhauer et al. (2006) found differences between trained claw trimmers in their ability to diagnose chronic laminitis, interdigital dermatitis or heel horn erosion, sole hemorrhage, and white line disease. Claw disorders can be grouped into infectious (hygiene) or laminitis (feed)related claw disorders depending on the cause of disease. For example, dermatitis and heel horn erosion are infectious disorders, whereas sole ulcer and white line disorder are laminitis-related claw disorders (Fjeldaas et al., 2007; Buch et al., 2011).

The heritabilities of claw disorders are generally low and genetic correlations among them vary between -0.19 and 0.95 (e.g., van der Waaij et al., 2005; Buch et al., 2011; Johansson et al., 2011). Genetic correlations among claw disorders and feet and leg conformation traits have been estimated by several researchers (e.g., van der Waaij et al., 2005; Laursen et al., 2009; Häggman et al., 2013). Laursen et al. (2009) found the 
highest genetic correlation for overall claw health with locomotion (0.46) and with rear leg rear view (0.21). Among single claw disorders and leg and conformation traits, van der Waaij et al. (2005) estimated that the highest genetic correlations were for foot angle with white line disease (0.64) and for locomotion with interdigital hyperplasia (0.82). Uggla et al. (2008) concluded that genetic correlations among claw health traits and feet and leg conformation traits in Swedish Red and Swedish Holstein were insufficient to select indirectly for claw health.

Currently, corkscrew claw is the only claw disorder included in routine genetic evaluation of Norwegian Red. This trait is recorded together with other conformation traits on first-lactation cows (Geno Breeding and AI Association, 2011). Recording corkscrew claw at claw trimming would probably be a more accurate measure, because the cow is fixed and each claw examined more thoroughly. Claw health recorded at claw trimming has, since 2004, been an integrated part of the Norwegian Dairy Herd Recording System, but has so far not been used for genetic evaluation.

The objective of this study was the first genetic analysis of Norwegian claw health records. The aims were to estimate heritabilities of and genetic correlations among claw disorders, for single disorder, grouped disorder, and overall claw disorder.

\section{MATERIALS AND METHODS}

\section{Data}

Data from the Norwegian Dairy Herd Recording System from 2004 to 2011 were used in the analyses. The data included 309,885 claw health records from 178,452 cows recorded at claw trimming. The claw trimmers recorded whether the cow had normal (healthy) claws or if one or more of 9 claw disorders were present (Table 1). Claw disorders included were corkscrew claw (CSC), heel horn erosion (HH), dermatitis (DE), sole ulcer (SU), white line disorder (WLD), hemorrhage of sole and white line (HSW), interdigital phlegmon (IDP), lameness (LAME), and acute trauma (AT). Identification of claw trimmer, date of claw trimming, and other disorders or remarks were also recorded. Claw trimmers were categorized into professional claw trimmers, other claw trimmers, farmers, and others such as veterinarians or veterinary students. Professional claw trimmers are certified by the Norwegian Cattle Health Services (Sogstad and Fjeldaas, 2008), whereas other claw trimmers and farmers lack certification. Professional claw trimmers have a unique code so that they can be identified when recording claw health, whereas other claw trimmers and farmers use a universal group code. A cow could have several claw disorders reported on the same day; however, the leg involved (front or rear) was not reported. Because reporting is voluntary, not all claw health records are reported to the central database and some herds fail to report healthy cows. In Norway, most herds do claw trimming once or occasionally twice per year, but not all cows are necessarily trimmed at each claw trimming.

The number of claw health records per year has increased gradually to about 70,000 in 2011 (Figure 1), and the number of herds reporting claw health records (Figure 2) has increased to approximately 3,000. On average, about $30 \%$ of the cows in a herd had at least one claw health record, and $23 \%$ of the claw health records noted a claw disorder. Frequencies of each of the single claw disorders have increased from 2004 to 2011, except for IDP, LAME, and AT (Table 2). In 2011, the frequency of single claw disorders ( $\%$ of all claw health records) varied from $0.2 \%$ (IDP) to $10 \%$ (CSC). Veterinarian-treated cases of IDP were not reported in the claw health recording, and therefore not included in these data. The frequency of IDP may therefore be higher than shown here. A total of 2,651 sires and 6,773 herds were represented in the data.

The average herd size for herds contributing with claw health data was 26 cows, with standard deviation (SD) of 17. On average, there were 110, 46, and 1.7 claw health records per sire (includes all available

Table 1. Definitions of normal claws and claw disorders included in the Norwegian claw health recording system (Refsum, 2012)

\begin{tabular}{lll}
\hline Claw health & Abbreviation & Definition \\
\hline Normal & & No claw disorders when examined under claw trimming \\
Corkscrew claw & CSC & Small to large twist in the abaxial wall on the lateral hind claws \\
Heel horn erosion & HH & Moderate to severe degree of erosion in the heel bulb with distinct V-shape \\
Dermatitis & DE & Dermatitis (bleeding, exuding, or wart-like) in front or rear in the interdigital claw \\
Sole ulcer & SU & Defect in the horn near the corium between the sole and heel bulb \\
White line disorder & WLD & Defect in the white line, in severe cases it can reach the corium \\
Hemorrhage of sole and white line & HSW & Hemorrhage of more than 20\% of the sole or white line or both \\
Interdigital phlegmon & IDP & Severe infection in the interdigital claw, with swelling of the leg \\
Lameness & LAME & Locomotion score $\geq 3$ \\
Acute trauma & AT & For example, fractures and dislocation of joint \\
\hline
\end{tabular}




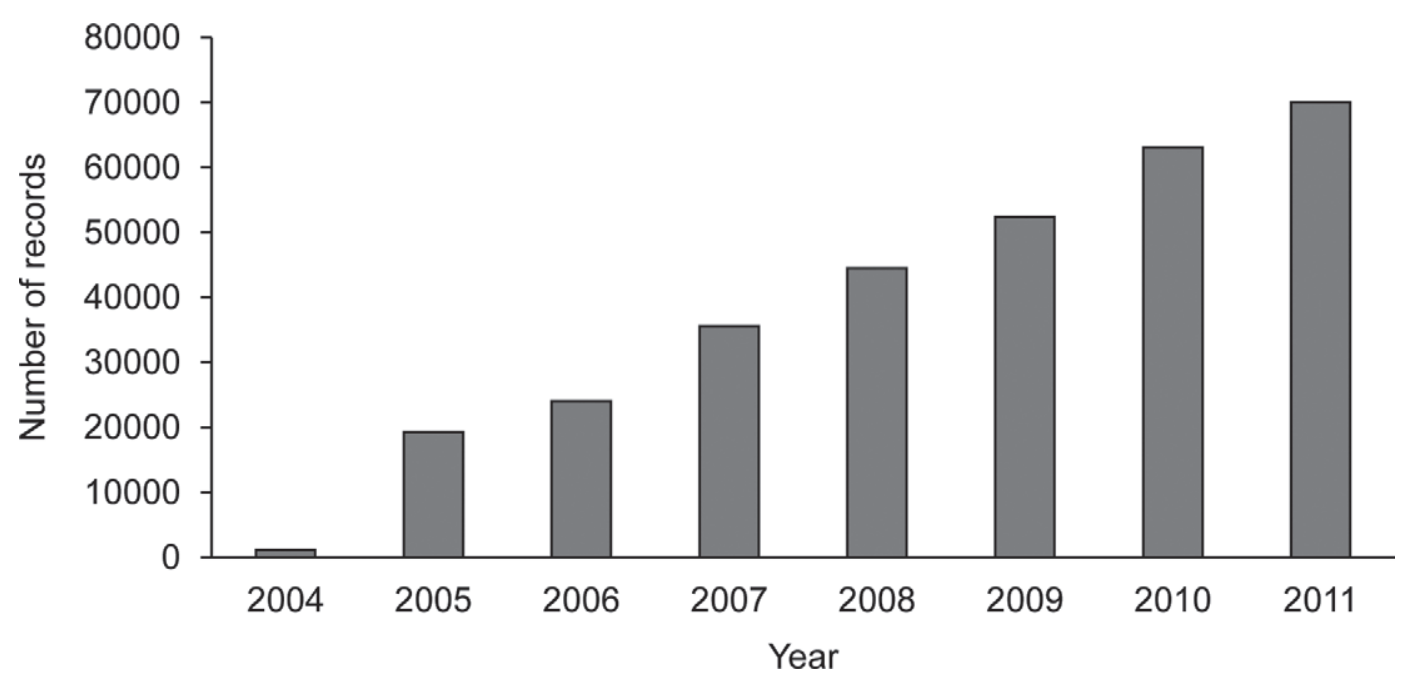

Figure 1. Number of claw health records per year.

records for both elite and young sires), herd, and cow, respectively, with corresponding SD of 406, 67, and 1 . The maximum number of records per sire, herd, and cow was $6,013,1,227$, and 18 , respectively. The average daughter group with claw health records for sires that got their first official proofs in 2010 and 2011 was 34 and 37 , respectively. Approximately $18 \%$ of the cows had 2 or more claw health records during one lactation.

\section{Data Editing}

Editing of the data was performed in SAS (SAS Institute, 2002). Only cows with claw health data were included in the analyses. Herds reporting less than $10 \%$ or fewer than 10 normal claw records from 2004 to 2011 were excluded; cows must have had Norwegian Red AI sire; and age at calving was within defined intervals. The intervals for calving age in months were as follows: first calving between 16 and $48 \mathrm{mo}$; second calving be- tween 26 and 61 mo; third calving between 36 and 74 mo; and fourth calving between 45 and 87 mo. After editing, the data set contained 204,892 claw health records from 141,659 cows, 1,904 sires, and 6,156 herds. The data set included no records of HSW before 2007, so it was smaller for this trait and contained 174,877 claw health records from 123,511 cows, 1,679 sires, and 5,637 herds.

\section{Trait Definitions}

Each single claw disorder was defined as a binary trait, 0 (normal) or 1 (disorder), for each cow and lactation. A lactation was defined from calving to $365 \mathrm{~d}$ after calving or, until next calving or culling if either occurred before $365 \mathrm{~d}$. Because some claw disorders had a low frequency (Table 3), grouping them is an option. Overall claw disorder (OCD) was defined based on whether or not the cow had at least one claw disorder

Table 2. Development of normal (healthy) claws and claw disorders (percentage of all claw trimming records) in Norway from 2004 to 2011

\begin{tabular}{lrrrrrrrr}
\hline & \multicolumn{7}{c}{ Year } \\
\cline { 2 - 9 } Claw health & 2004 & 2005 & 2006 & 2007 & 2008 & 2009 & 2010 & 2011 \\
\hline Normal & 91.1 & 83.2 & 85.2 & 85.9 & 77.2 & 77.2 & 73.8 & 69.8 \\
Corkscrew claw & 4.0 & 7.6 & 6.8 & 6.8 & 9.2 & 9.5 & 10.2 & 11.0 \\
Heel horn erosion & 1.0 & 1.7 & 1.9 & 2.2 & 4.0 & 4.0 & 4.8 & 6.6 \\
Dermatitis & 0.1 & 0.7 & 0.6 & 0.7 & 1.7 & 1.4 & 1.8 & 2.6 \\
Sole ulcer & 0.9 & 2.4 & 2.0 & 1.8 & 2.2 & 2.2 & 2.5 & 2.5 \\
White line disorder & 0.3 & 1.9 & 1.7 & 1.4 & 2.3 & 2.3 & 3.1 & 3.9 \\
Hemorrhage of sole & 0 & 0 & 0 & 0.2 & 1.9 & 1.7 & 2.2 & 2.3 \\
and white line & 0.1 & 0.2 & 0.3 & 0.1 & 0.1 & 0.2 & 0.3 & 0.2 \\
Interdigital phlegmon & 2.7 & 2.2 & 1.4 & 1.1 & 1.3 & 1.1 & 1.1 & 1.0 \\
Lameness & 0.1 & 0.1 & 0.2 & 0.2 & 0.2 & 0.3 & 0.2 & 0.1 \\
Acute trauma & & & & & & & & \\
\hline
\end{tabular}


(any of the 9) recorded during a lactation. Two groups of claw disorders were also defined by the cause of the disorder: infectious claw disorders (INFEC, containing $\mathrm{DE}, \mathrm{HH}$, and IDP), and laminitis-related claw disorders (LAMIN, containing SU, WLD, and HSW). The mean frequency of the claw disorders and groups of claw disorders (Table 3) ranged from 0.1 to $21.3 \%$. For each single trait or group of claw disorders, only the first occurrence per lactation was used. The time of the corresponding claw trimming was included in the analyses. For healthy cows, the time of first trimming was used.

\section{Statistical Analyses}

Heritabilities and genetic correlations were inferred by a Bayesian approach using Gibbs sampling. Threshold sire models (e.g., Gianola and Foulley, 1983) were used for analyses. Univariate analyses of all 9 single traits and the 3 groups were performed. Multivariate models were used to estimate genetic correlations among the 5 single claw disorders with highest frequency: CSC, DE, $\mathrm{HH}, \mathrm{SU}$, and WLD, and among the 2 groups of claw disorders (INFEC and LAMIN) and CSC. In matrix notation, the threshold sire model used was

$$
\lambda=\mathbf{X} \boldsymbol{\beta}+\mathbf{Z}_{\mathbf{h}} \mathbf{h}+\mathbf{Z}_{\mathbf{s}} \mathbf{s}+\mathbf{e},
$$

where $\boldsymbol{\lambda}$ is a vector of unobserved liabilities for the trait; $\boldsymbol{\beta}$ is a vector of systematic effects, including lactation number, calving year and month, time for claw trimming (months after calving), and claw trimmer; $\mathbf{h}$ is a vector of random herd effects with 6,156 levels, except for HSW, which had 5,637 levels; $\mathbf{s}$ is a vector of sire effects with 20,886 levels, e is a vector of residuals, and $\mathbf{X}, \mathbf{Z}_{\mathbf{h}}$, and $\mathbf{Z}_{\mathrm{s}}$ are the corresponding incidence
Table 3. Mean frequency of single and grouped claw disorders analyzed, where cows have 1 record per trait per lactation

\begin{tabular}{lc}
\hline Trait & Frequency, \% \\
\hline Corkscrew claw & 10.2 \\
Heel horn erosion & 4.4 \\
Dermatitis & 1.7 \\
Sole ulcer & 2.7 \\
White line disorders & 2.9 \\
Hemorrhage of sole and white line & 2.2 \\
Interdigital phlegmon & 0.2 \\
Lameness & 1.3 \\
Acute trauma & 0.1 \\
Infectious claw disorders & 5.7 \\
Laminitis-related claw disorders & 6.8 \\
Overall claw disorder & 21.3 \\
\hline
\end{tabular}

matrices. Lactation number had 4 classes, where the fourth class included lactations 4 to 13 . Calving year and month had 93 classes from April 2004 to December 2011, where the first class included all records before April 2004 because of few records in these months. Time for claw trimming, in months after calving, had 12 classes. Claw trimmers were divided into 4 classes: (1) professional claw trimmers with 58,633 claw health records; (2) other claw trimmers with 142,687 records; (3) farmers with 35,793 records; and (4) other persons with 6,045 records. The HSW had 72 classes for calving year and month (January 2007 to December 2011), where months before January 2007 were merged. Because of the low frequency of IDP and AT (Table 3 ), a reduced model without effect of calving year and month were used for these traits, to avoid extreme category problems.

For the univariate threshold models it was assumed that $\mathbf{s} \sim N\left(0, \mathbf{A} \sigma_{s}^{2}\right), \mathbf{h} \sim N\left(0, \sigma_{h}^{2}\right)$, and $\mathbf{e} \sim N(0,1)$, where $\sigma_{s}^{2}$ is sire variance, $\sigma_{h}^{2}$ is herd variance, and the residual

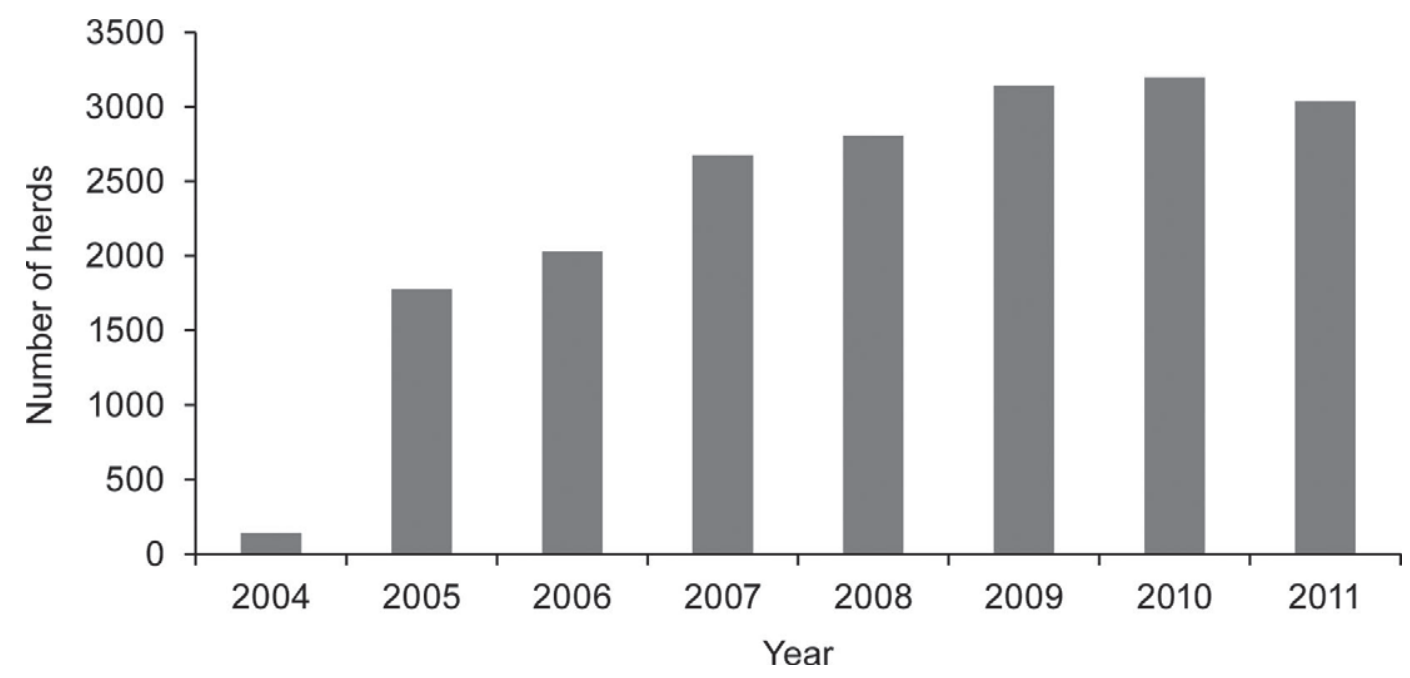

Figure 2. Number of herds with claw health records per year. 
variance $\left(\sigma_{e}^{2}\right)$ was set equal to $1 ; \mathbf{A}$ is the additive genetic relationship matrix. The pedigree file contained 20,886 animals, including sires of cows with claw health records, and their pedigree traced back as far as possible. In the multivariate analyses, it was assumed that $\operatorname{var}(\mathbf{s})=\mathbf{G} \otimes \mathbf{A}, \operatorname{var}(\mathbf{h})=\mathbf{H} \otimes \mathbf{I}$, and $\operatorname{var}(\mathbf{r})=\mathbf{R} \otimes \mathbf{I}$, where $\mathbf{I}$ is an identity matrix and $\mathbf{G}, \mathbf{H}$, and $\mathbf{R}$ are the $5 \times 5$ matrices containing genetic, herd, and residual variances, respectively, and covariance among the 5 traits. Heritability $\left(h^{2}\right)$ was calculated using

$$
h^{2}=\frac{4 \times \sigma_{s}^{2}}{\sigma_{s}^{2}+\sigma_{e}^{2}} .
$$

\section{Sampling and Convergence Diagnostics}

The RJMC procedure of the DMU software (Madsen and Jensen, 2008) was used for analyses. Test for convergence were done using the Raftery and Lewis method in BOA (Bayesian Output Analyses; Smith, 2005). For the univariate analyses, burn-in was set to 10,000 iterations for all traits, and the total number of iterations varied between 130,000 and 575,000. For the multivariate analyses, the first 40,000 samples were discarded as burn-in and the total numbers of iterations for the 5 single disorders and the 3 groups were 900,000 and 750,000 , respectively.

\section{RESULTS AND DISCUSSION}

\section{Fixed Effects}

Effects of claw trimmer were similar for $\mathrm{HH}$, DE, INFEC, WLD, HSW, SU, and LAMIN, with lower frequencies when farmers performed claw trimming; for CSC, almost no differences were detected between the 4 categorizes of claw trimmers. Calving year and month had an effect but showed no clear trend for any of the claw disorders. Stage of lactation showed a peak 3 to 5 mo after calving for SU and HSW. Most of the other traits showed a slight increase in number of claw disorders in later stage of lactation. The effect of lactation number for OCD indicated more cases of claw disorders in later lactations.

\section{Single Claw Disorders}

Heritabilities. The posterior mean of heritability of liability from univariate analyses of single claw disorders ranged from 0.04 (LAME and AT) to 0.23 (CSC; Table 4). The SD of the heritabilities was low, ranging from 0.01 to 0.03 , except for IDP, where SD was 0.06 . The 95\% highest probability density interval (95\% HPD) presented in Table 4 did not include zero for any of the disorders. The widest 95\% HPD were found for DE and IDP and the narrowest for HSW and LAME (Table 4). Results from the multivariate model (Table 5) were in accordance with the univariate analyses (Table 4). The posterior distribution of heritability of liability for the 5 claw disorders was symmetric, as shown in Figure 3, with SD ranging from $0.01(\mathrm{HH})$ to 0.03 (DE; Table 5). Results from this study were in accordance with results found by Swalve et al. (2008) and Buch et al. (2011), where heritability at the underlying scale ranged from 0.07 to 0.17 for similar claw disorders. In contrast, Huang and Shanks (1995) found lower heritability for CSC (0.036) and SU (0.024) and higher heritabilities for HH (0.144) and WLD (0.150). This could be due to different scoring and definitions of the claw disorders and because their data came from a research herd. van der Waaij et al. (2005) found similar heritabilities using linear and threshold models, ranging from 0.01 to 0.10 . Other studies have investigated different claw disorders and presented heritabilities from 0.01 to 0.12 on the observed scale (Koenig et al., 2005; van der Linde et al., 2010; Johansson et al., 2011).

Genetic Correlations. Posterior mean of genetic correlations among the 5 claw disorders ranged between 0.02 and 0.79 , with posterior SD between 0.01 and 0.14 (Table 5). The highest genetic correlations were found between WLD and SU (0.79) and between $\mathrm{DE}$ and $\mathrm{HH}$ (0.65). Genetic correlations among CSC, $\mathrm{DE}$, and WLD were all close to zero $(\leq 0.04)$. Figure 4 shows the posterior distributions of genetic correlations within and between some of the single claw disorders that were grouped. The distributions were slightly skewed to the left, except for the genetic correlation between WLD and DE (Figure 4). The 95\% HPD for the genetic correlations between WLD and SU, and between DE and HH ranged from 0.63 to 0.92 , and 0.46 to 0.81 , respectively (Table 5). The $95 \%$ HPD for 6 of the genetic correlations (Table 5) included zero, of which 5 involved WLD or CSC. Figure 4 shows 2 of these distributions: WLD and DE, and $\mathrm{HH}$ and CSC. High correlations may be expected between $\mathrm{DE}$ and $\mathrm{HH}$, because both are infectious disorders, caused by bacteria and related to poor hygiene and wet flooring. The claws lose hardness (Webster, 1993) and become more available for infectious bacteria in such an environment. A high-concentrate feeding regimen increases the risk of capsule disruption of the claw that in turn increases the risk for SU and WLD (Webster, 1993). van der Linde et al. (2010) estimated genetic correlations among sole hemorrhage, digital dermatitis, interdigital dermatitis, and $\mathrm{SU}$, and these varied between -0.33 and 0.93 . Buch et al. (2011) estimated a genetic correlation of $0.87(P$ $<0.05)$ between $\mathrm{DE}$ and $\mathrm{HH}$, whereas genetic correla- 
Table 4. Posterior mean, standard deviation (SD), and $95 \%$ highest probability density interval (95\% HPD) of heritability of liability and posterior mean and SD of sire variance $\left(\sigma_{s}^{2}\right)$ and herd variance $\left(\sigma_{h}^{2}\right)$ from a univariate threshold model analyses of claw disorders

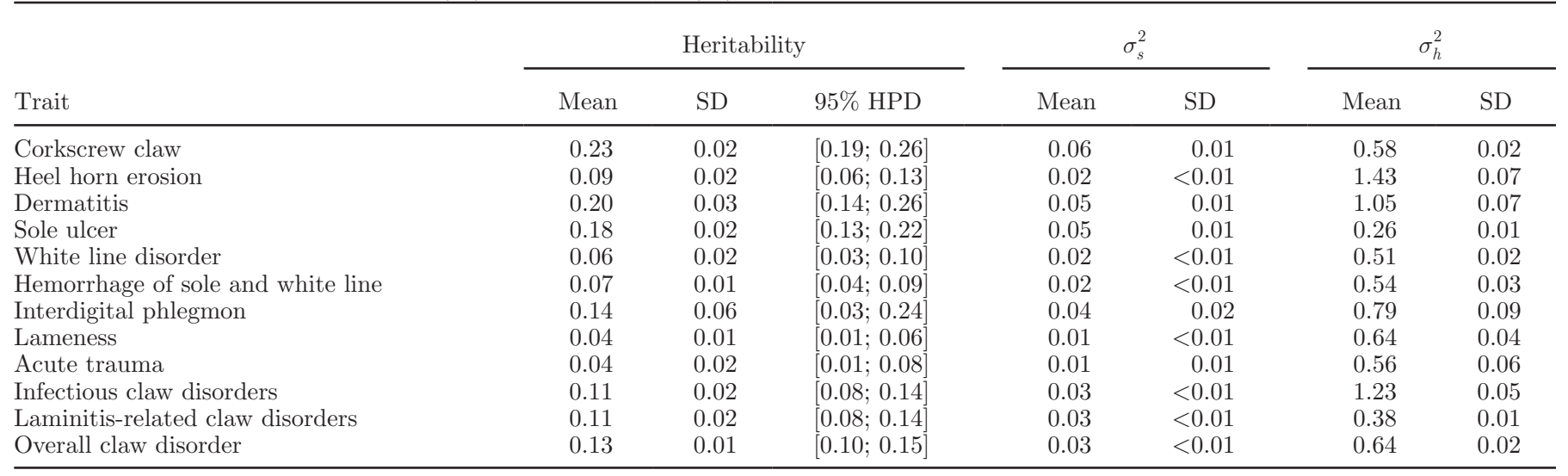

tions between SU and DE (-0.19) and HH (0.13) were not different from zero. Genetic correlation between SU and $\mathrm{HH}$ were in contrast to the estimate of 0.42 in this study (Table 5). Koenig et al. (2005) found a moderate to high genetic correlation between digital dermatitis and SU (0.56).

\section{Grouped Claw Disorders}

Heritability. The posterior mean of heritability of liability from the univariate model was 0.11 for both INFEC and LAMIN (Table 4), and the results from multivariate analyses were almost the same (Table 6).
The heritability of CSC was 0.23 in both models (Tables 4 and 6). For OCD, the posterior mean of heritability of liability was 0.13 (SD 0.01) and the $95 \%$ HPD ranged from 0.10 to 0.15 . The heritability of OCD was higher than that for INFEC and LAMIN, most likely because CSC was included, which has the highest frequency and heritability of all claw disorders. The estimated heritability of OCD was in accordance with Buttchereit et al. (2012) but higher than the heritability on the underlying scale found by Häggman et al. (2013).

Genetic Correlations. The posterior mean of the genetic correlations between INFEC and CSC, LAMIN and CSC, and LAMIN and INFEC were 0.06, 0.31,

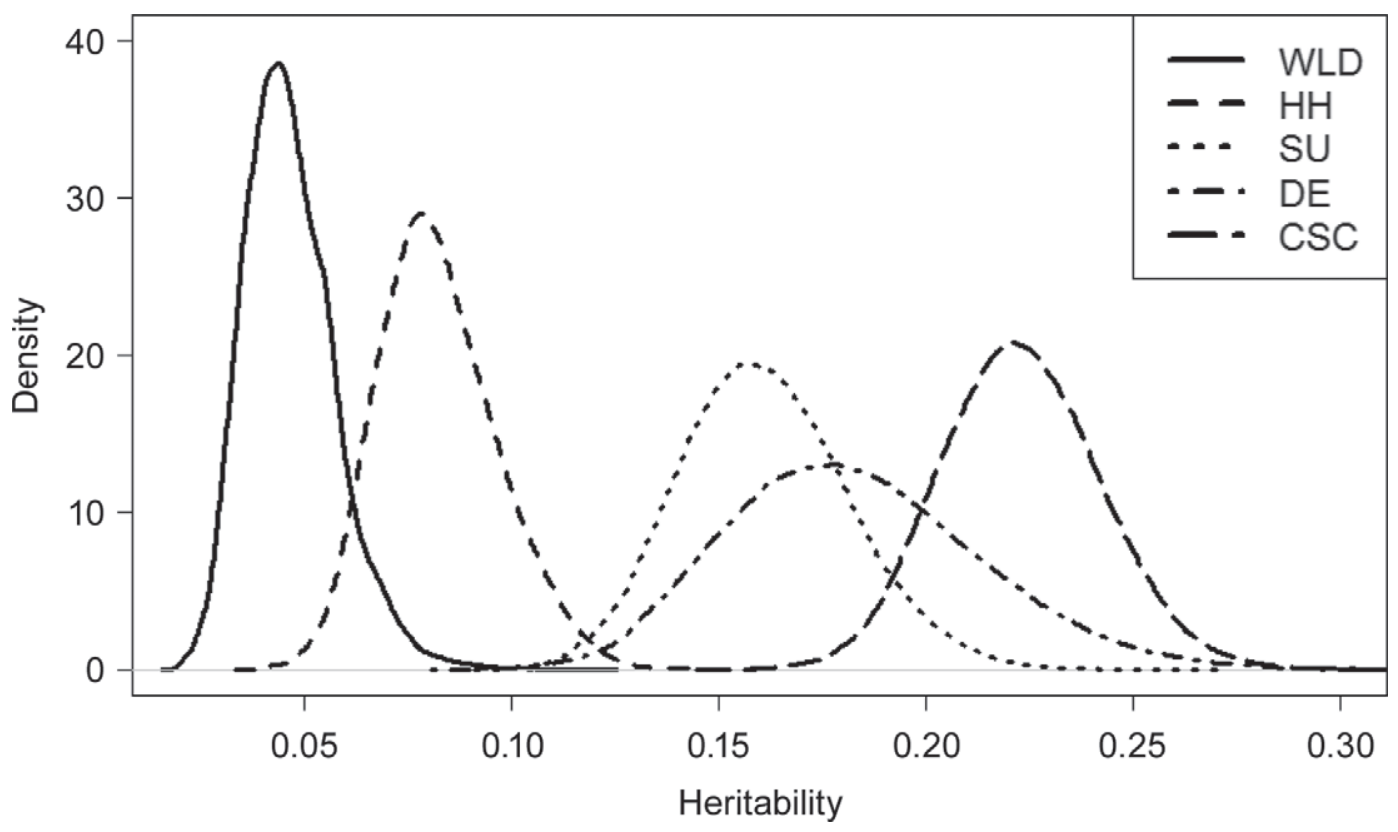

Figure 3. Posterior distribution of heritability of liability for (from left) white line disorder (WLD), heel horn erosion (HH), sole ulcer (SU), dermatitis (DE), and corkscrew claw (CSC), from multivariate analyses. 
Table 5. Posterior mean (SD in parentheses, 95\% highest probability density intervals in brackets) of heritability of liability (on diagonal) and genetic correlation (below diagonal) among corkscrew claw (CSC), heel horn erosion $(\mathrm{HH})$, dermatitis $(\mathrm{DE})$, sole ulcer $(\mathrm{SU})$, and white line disorder (WLD)

\begin{tabular}{|c|c|c|c|c|c|}
\hline & CSC & $\mathrm{HH}$ & $\mathrm{DE}$ & $\mathrm{SU}$ & WLD \\
\hline $\mathrm{CSC}$ & $\begin{array}{c}0.22(0.02) \\
{[0.19 ; 0.26]}\end{array}$ & & & & \\
\hline $\mathrm{HH}$ & $\begin{array}{r}0.13(0.10) \\
{[-0.06 ; 0.32]}\end{array}$ & $\begin{array}{c}0.08(0.01) \\
{[0.06 ; 0.11]}\end{array}$ & & & \\
\hline $\mathrm{DE}$ & $\begin{array}{r}0.02(0.10) \\
{[-0.18 ; 0.20]}\end{array}$ & $\begin{array}{c}0.65(0.09) \\
{[0.46 ; 0.81]}\end{array}$ & $\begin{array}{c}0.18(0.03) \\
{[0.13 ; 0.25]}\end{array}$ & & \\
\hline $\mathrm{SU}$ & $\begin{array}{r}0.42(0.08) \\
{[0.27 ; 0.56]}\end{array}$ & $\begin{array}{c}0.42(0.10) \\
{[0.23 ; 0.60]}\end{array}$ & $\begin{array}{r}0.19(0.11) \\
{[-0.02 ; 0.39]}\end{array}$ & $\begin{array}{c}0.16(0.02) \\
{[0.12 ; 0.20]}\end{array}$ & \\
\hline WLD & $\begin{array}{r}0.04(0.11) \\
{[-0.18 ; 0.26]}\end{array}$ & $\begin{array}{r}0.22(0.14) \\
{[-0.06 ; 0.49]}\end{array}$ & $\begin{array}{r}0.04(0.14) \\
{[-0.22 ; 0.32]}\end{array}$ & $\begin{array}{c}0.79(0.08) \\
{[0.63 ; 0.92]}\end{array}$ & $\begin{array}{c}0.05(0.01) \\
{[0.03 ; 0.07]}\end{array}$ \\
\hline
\end{tabular}

and 0.24 , respectively (Table 6). The $95 \%$ HPD for the genetic correlation between INFEC and CSC included zero ( -0.12 to 0.23$)$, whereas between LAMIN and CSC and LAMIN and INFEC, the 95\% HPD ranged from 0.15 to 0.46 and from 0.04 to 0.44 , respectively (Table 6). The genetic correlations among the single claw disorders in the 2 groups INFEC and LAMIN were high within groups and lower between groups (Table 5). Other authors found moderate to high genetic correlations among single claw disorders grouped in a similar manner as in this study (van der Linde et al., 2010; Buch et al., 2011; Johansson et al., 2011). van der Linde et al. (2010) estimated genetic correlations between hygiene-related claw disorders (digital dermatitis, interdigital dermatitis, and interdigital hyperplasia) and laminitis-related claw disorders (sole hemorrhage, SU, and WLD), which ranged from -0.35 to 0.18. Buch et al. (2011) defined hygiene-related (DE and $\mathrm{HH}$ ) and laminitis-related (sole hemorrhage and SU) hoof diseases based on high genetic correlations between the claw disorders within each group, and low genetic correlations between the single disorders in the 2 groups. The highest correlations were found between sole hemorrhage and SU (van der Linde et al., 2010; Buch et al., 2011), dermatitis and heel horn erosion (Buch et al., 2011), and digital dermatitis and interdigital dermatitis (van der Linde et al., 2010). Genetic correlations among CSC, infectious-related, and feedrelated traits found by Johansson et al. (2011) varied between -0.13 and 0.40 . Because the single claw dis-

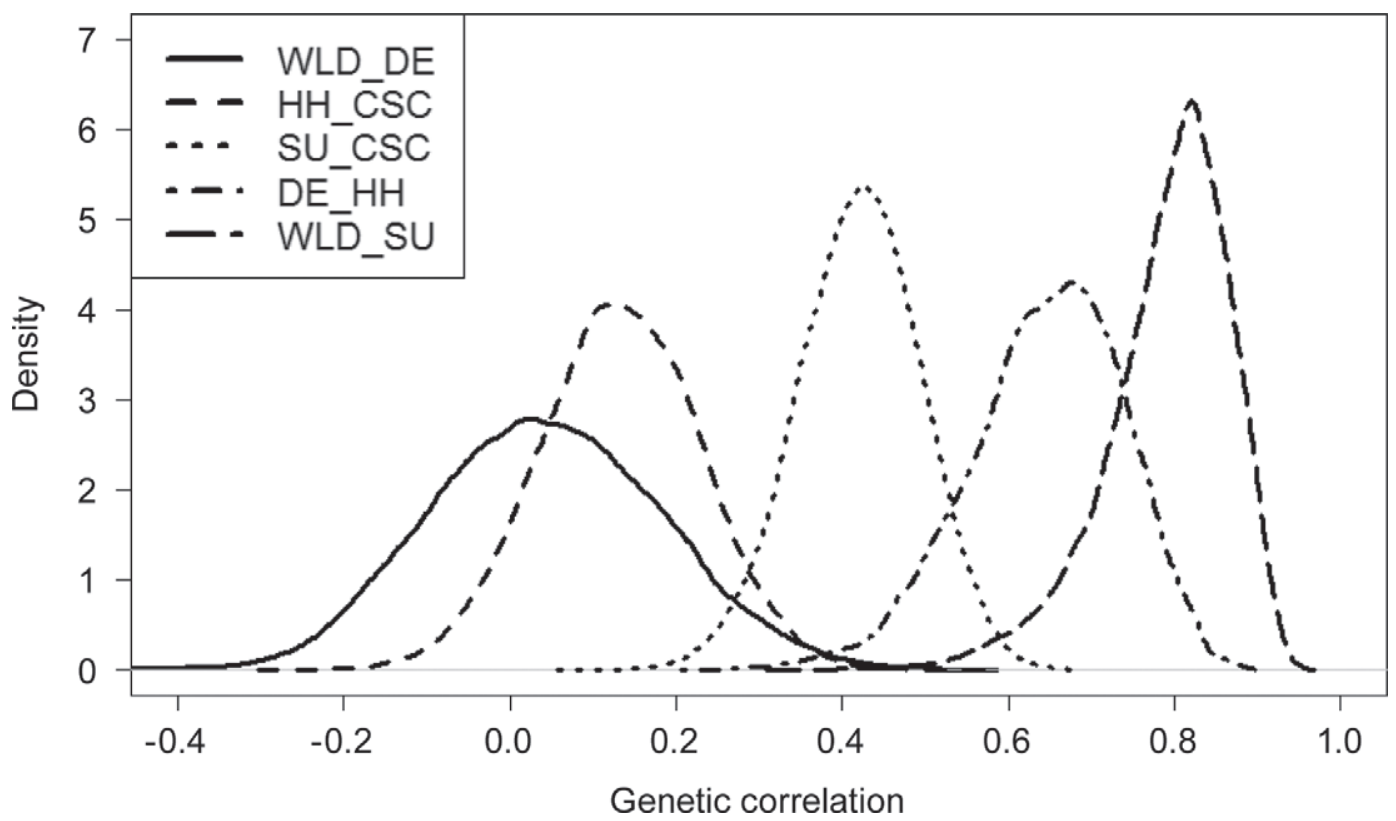

Figure 4. Posterior distribution of genetic correlation between (from left) white line disorder and dermatitis (WLD_DE), heel horn erosion and corkscrew claw (HH_CSC), sole ulcer and corkscrew claw (SU_CSC), dermatitis and heel horn erosion (DE_HH), and white line disorder and sole ulcer (WLD_SU). 
Table 6. Posterior mean (SD in parentheses, $95 \%$ highest probability density intervals in brackets) of heritability of liability (on diagonal) and genetic correlation (below diagonal) among corkscrew claw (CSC), infectious claw disorders (INFEC), and laminitis-related claw disorders (LAMIN)

\begin{tabular}{lrrr}
\hline & \multicolumn{1}{c}{ CSC } & INFEC & LAMIN \\
\hline CSC & $0.23(0.02)$ & & \\
& {$[0.19 ; 0.26]$} & & \\
INFEC & $0.06(0.09)$ & $0.10(0.02)$ & \\
& {$[-0.12 ; 0.23]$} & {$[0.07 ; 0.13]$} & \\
LAMIN & $0.31(0.08)$ & $0.24(0.10)$ & $0.10(0.01)$ \\
& {$[0.15 ; 0.46]$} & {$[0.04 ; 0.44]$} & {$[0.08 ; 0.13]$} \\
\hline
\end{tabular}

orders showed low frequency, a grouping of these could be advantageous for genetic evaluation to get higher prevalence for the defined claw trait. This is only valid if the genetic correlations among claw disorders within each group are high, so it becomes reasonable to assume they are almost the same trait or are affected by some common genes.

\section{Herd and Residual Correlations}

The posterior mean of residual correlations were all close to zero ( -0.14 to 0.14 ; Tables 7 and 8 ), except for the correlation between DE and $\mathrm{HH}$ (0.34). Posterior mean of herd correlations ranged from 0.26 (DE and $\mathrm{CSC}$ ) to 0.65 (DE and $\mathrm{HH}$ ) for the 5 claw disorders analyzed in the multivariate model (Table 7), and from 0.37 to 0.55 for CSC, INFEC, and LAMIN (Table 8). Dermatitis and $\mathrm{HH}$ had the highest mean herd variance together with INFEC (Table 4), whereas SU and LAMIN had the lowest herd variance. The results indicate that different claw disorders are affected by similar environmental effects, as shown by other authors (e.g., Nielsen et al., 1997; Bielfeldt et al., 2005). Herd factors such as types of flooring, cubicle, nutrition, and feeding system can affect claw disorders. For example, small or poorly formed cubicles can reduce the lying time and thereby increase the risk of claw disorders (Leonard et al., 1996) such as SU and WLD.

The model used in the present study did not include the permanent environmental effect of cow, because few cows had more than one record and most of the cows were healthy. The herd effect would therefore include a possible permanent effect of cow.

\section{Claw Health Data}

Not every cow in a herd had a claw health record because claw trimming may not have been needed at a visit. Such cows may be healthy, but not necessarily, because some claw disorders can only be observed at claw trimming. To define healthy cows, one alternative is to include only cows with claw health records in the analyses, another is to include all cows in a herd and assume that cows without claw health records are healthy. The latter would underestimate the frequency of claw disorders, whereas excluding them would lead to an overestimation. The frequencies of single claw disorders in Norwegian Red were generally lower than those in other Nordic countries (Johansson et al., 2011), except CSC, which had considerably higher frequency. In Norway, DE includes both digital and interdigital dermatitis, because few cases of digital dermatitis were found (Sogstad et al., 2005). Our results for DE are therefore difficult to compare with results from other studies (e.g., Koenig et al., 2005; Swalve et al., 2008; Häggman et al., 2013) in which the 2 traits (digital dermatitis and interdigital dermatitis) are defined as separate traits.

The accuracy of diagnosis of claw disorders may vary between categories of claw trimmers. Farmers who only perform claw trimming in their own herd may have less experience in diagnosis of claw disorders. The group of "other" claw trimmers had the greatest number of claw health records, but individual claw trimmers cannot be distinguished within the group. Experience in diagnosing claw disorders and the number of claw trimmings per person per year will vary within this group.

More daughters with claw health information per sire would be beneficial for genetic evaluation. At present, the number of daughters with claw health records available at the time when the sires get their first official proof is low compared with other health traits in Norwegian Red. Denmark, Finland, and Sweden implemented a claw health index in 2011, and the average daughter groups per sire varied from 11 to 59 between

Table 7. Posterior mean (SD) of herd correlation (above diagonal) and residual correlation (below diagonal) among corkscrew claw (CSC), heel horn erosion (HH), dermatitis (DE), sole ulcer (SU), and white line disorder (WLD)

\begin{tabular}{lrcccc}
\hline & CSC & HH & DE & SU & WLD \\
\hline CSC & & $0.40(0.02)$ & $0.26(0.03)$ & $0.37(0.02)$ & $0.46(0.02)$ \\
HH & $-0.06(0.01)$ & & $0.65(0.02)$ & $0.44(0.02)$ & $0.54(0.02)$ \\
DE & $-0.14(0.02)$ & $0.34(0.02)$ & & $0.47(0.03)$ & $0.52(0.03)$ \\
SU & $0.06(0.01)$ & $0.11(0.02)$ & $0.07(0.02)$ & & $0.51(0.02)$ \\
WLD & $0.01(0.01)$ & $0.08(0.02)$ & $0.00(0.02)$ & $0.14(0.02)$ & \\
\hline
\end{tabular}


Table 8. Posterior mean (SD) of herd correlation (above diagonal) and residual correlation (below diagonal) among corkscrew claw (CSC), infectious claw disorders (INFEC), and laminitis-related claw disorders (LAMIN)

\begin{tabular}{lrcc}
\hline & \multicolumn{1}{c}{ CSC } & INFEC & LAMIN \\
\hline CSC & & $0.37(0.02)$ & $0.45(0.02)$ \\
INFEC & $-0.10(0.01)$ & & $0.55(0.02)$ \\
LAMIN & $0.02(0.01)$ & $0.02(0.01)$ & \\
\hline
\end{tabular}

breeds (Holstein and Red Dairy Cattle) and countries (Johansson et al., 2011). Claw health status recorded at claw trimming provides useful information that can be used for genetic evaluation and gives opportunities for more efficient selection for improved claw health in Norwegian Red.

\section{CONCLUSIONS}

Claw disorders are heritable, and CSC, DE, and SU have the highest heritabilities $(\geq 0.18)$. The genetic correlations among the 5 most frequent claw disorders support the grouping of claw disorders into CSC, INFEC, and LAMIN, which could be a way to include claw health in the breeding scheme. Including claw health in the total merit index will have positive effects on the prevalence of claw disorders in the long term.

\section{ACKNOWLEDGMENTS}

The authors thank all claw trimmers and farmers who reported claw health data, the Norwegian Dairy Herd Recording System and the Norwegian Cattle Health Service (Ås, Norway) for access to data, the Norwegian Research Council (Oslo, Norway) and Geno Breeding and AI Association (Ås, Norway) for funding, and Åse Margrethe Sogstad (Norwegian Cattle Health Service, Ås, Norway) for help in interpreting the claw health data.

\section{REFERENCES}

Bielfeldt, J. C., R. Badertscher, K.-H. Tölle, and J. Krieter. 2005. Risk factors influencing lameness and claw disorders in dairy cows. Livest. Prod. Sci. 95:265-271. http://dx.doi.org/10.1016/j. livprodsci.2004.12.005.

Buch, L. H., A. C. Sørensen, J. Lassen, P. Berg, J.-Å. Eriksson, J. H. Jakobsen, and M. K. Sørensen. 2011. Hygiene-related and feedrelated hoof diseases show different patterns of genetic correlations to clinical mastitis and female fertility. J. Dairy Sci. 94:15401551. http://dx.doi.org/10.3168/jds.2010-3137.

Buttchereit, N., E. Stamer, W. Junge, and G. Thaller. 2012. Genetic parameters for energy balance, fat/protein ratio, body condition score and disease traits in German Holstein cows. J. Anim. Breed. Genet. 129:280-288. http://dx.doi.org/10.1111/j.14390388.2011.00976.x.

Enting, H., D. Kooij, A. A. Dijkhuizen, R. B. M. Huirne, and E. N. Noordhuizen-Stassen. 1997. Economic losses due to clinical lameness in dairy cattle. Livest. Prod. Sci. 49:259-267.
Fjeldaas, T., O. Nafstad, B. Fredriksen, G. Ringdal, and Å. M. Sogstad. 2007. Claw and limb disorders in 12 Norwegian beef-cow herds. Acta Vet. Scand. 49:24.

Fjeldaas, T., A. M. Sogstad, and O. Østerås. 2011. Locomotion and claw disorders in Norwegian dairy cows housed in freestalls with slatted concrete, solid concrete, or solid rubber flooring in the alleys. J. Dairy Sci. 94:1243-1255. http://dx.doi.org/10.3168/ jds.2010-3173.

Geno Breeding and AI Association. 2011.Eksteriør hos NRF-kyr. Beskrivelse av eksteriørvurderingene. Accessed Oct. 18, 2012 http://www.geno.no/Global/Geno.no/02\%20Dokumenter/For\%20 avlsrådgivere/Geno\%20Kvigemålingsbrosjyre\%20korr3\%20juni11. pdf. (In Norwegian).

Gianola, D., and J. L. Foulley. 1983. Sire evaluation for ordered categorical data with a threshold model. Genet. Sel. Evol. 15:201224. http://dx.doi.org/10.1186/1297-9686-15-2-201.

Häggman, J., J. Juga, M. J. Sillanpää, and R. Thompson. 2013. Genetic parameters for claw health and feet and leg conformation traits in Finnish Ayrshire cows. J. Anim. Breed. Genet. 130:89 97. http://dx.doi.org/10.1111/j.1439-0388.2012.01007.x.

Holzhauer, M., C. J. M. Bartels, B. H. P. van den Borne, and G. van Schaik. 2006. Intra-class correlation attributable to claw trimmers scoring common hind-claw disorders in Dutch dairy herds. Prev. Vet. Med. 75:47-55. http://dx.doi.org/10.1016/j. prevetmed.2006.01.013.

Huang, Y. C., and R. D. Shanks. 1995. Within-herd estimates of heritabilities for six hoof characteristics and impact of dispersion of discrete severity scores on estimates. Livest. Prod. Sci. 44:107114.

Johansson, K., J.-Å. Eriksson, U. S. Nielsen, J. Pösö, and G. P. Aamand. 2011. Genetic evaluation of claw health in Denmark, Finland and Sweden. Interbull Bull. 44:224-228.

Koenig, S., A. R. Sharifi, H. Wentrot, D. Landmann, M. Eise, and H. Simianer. 2005. Genetic parameters of claw and foot disorders estimated with logistic models. J. Dairy Sci. 88:3316-3325.

Laursen, M. V., D. Boelling, and T. Mark. 2009. Genetic parameters for claw and leg health, foot and leg conformation, and locomotion in Danish Holsteins. J. Dairy Sci. 92:1770-1777. http://dx.doi. org $/ 10.3168 /$ jds.2008-1388.

Leonard, F. C., J. M. O'Connell, and K. J. O'Farrell. 1996. Effect of overcrowding on claw health in first-calved Friesian heifers. Br. Vet. J. 152:459-472.

Madsen, P., and J. Jensen. 2008. A User's Guide to DMU. A package for analysing multivariate mixed models. Version 6, release 4.7. University of Aarhus, Faculty Agricultural Science (DJF), Department of Genetics and Biotechnology, Research Center Foulum, Tjele, Denmark.

Nielsen, U. S., G. A. Pedersen, J. Pedersen, and J. Jensen. 1997. Genetic correlations among health traits in different lactations. Interbull Bull. 15:68-77.

Østerås, O., H. Solbu, A. O. Refsdal, T. Roalkvam, O. Filseth, and A. Minsaas. 2007. Results and evaluation of thirty years of health recordings in the Norwegian dairy cattle population. J. Dairy Sci. 90:4483-4497. http://dx.doi.org/10.3168/jds.2007-0030.

Refsum, T. 2012. Referansekodeverket for husdyrsjukdommer i Norge. Animalia, Helsetjeneseten for storfe, Helsetjenesten for geit and Koorimp. Accessed Oct. 18, 2012. http://www.animalia.no/ upload/FIler\%20til\%20nedlasting/HT-Fjørfe/25.09.2012\%20-\%20 Referansekodeverk\%20for\%20husdyrsjukdommer\%20i\%20Norge. pdf. (In Norwegian).

SAS Institute. 2002. SAS software. Version 9.2. SAS Institute Inc. Cary, NC.

Simensen, E., O. Østerås, K. E. Bøe, C. Kielland, L. E. Ruud, and G. Næss. 2010. Housing system and herd size interactions in Norwegian Dairy herds; associations with performance and disease incidence. Acta Vet. Scand. 52:14. http://dx.doi.org/10.1186/17510147-52-14.

Smith, B. J. 2005. Bayesian output analyses program (BOA): Version 1.1 user's manual. Accessed Oct. 18, 2012. http://www. public-health.uiowa.edu/boa/boa.pdf. 
Sogstad, A. M., and T. Fjeldaas. 2008. Monitoring claw health and certification of claw trimmers in Norway. Pages 197-199 in Proc. 15th Int. Symp. 7th Conf. Lameness in Ruminants, Kuopio, Finland. Savonia University of Applied Sciences, Finland.

Sogstad, Å. M., T. Fjeldaas, O. Østerås, and K. P. Forshell. 2005. Prevalence of claw lesions in Norwegian dairy cattle housed in tie stalls and free stalls. Prev. Vet. Med. 70:191-209. http://dx.doi. org/10.1016/j.prevetmed.2005.03.005.

Sogstad, A. M., O. Østerås, and T. Fjeldaas. 2006. Bovine claw and limb disorders related to reproductive performance and production diseases. J. Dairy Sci. 89:2519-2528.

Sogstad, Å. M., O. Østerås, T. Fjeldaas, and O. Nafstad. 2007a. Bovine claw and limb disorders related to culling and carcass characteristics. Livest. Sci. 106:87-95. http://dx.doi.org/10.1016/j livsci.2006.07.003.

Sogstad, A. M., O. Østerås, T. Fjeldaas, and A. O. Refsdal. 2007b. Bovine claw and limb disorders at claw trimming related to milk yield. J. Dairy Sci. 90:749-759.

Swalve, H. H., H. Alkhoder, and R. Pijl. 2008. Estimates for breeding values for sires based on diagnoses recorded at hoof trimming:
Relationship with EBV for conformation traits. Interbull Bull. 38:87-90.

Uggla, E., J. H. Jakobsen, C. Bergsten, J.-A. Eriksson, and E. Strandberg. 2008. Genetic correlations between claw health and feet and leg conformation traits in Swedish dairy cows. Interbull Bull. 38:91-95.

van der Linde, C., G. de Jong, E. P. C. Koenen, and H. Eding. 2010 Claw health index for Dutch dairy cattle based on claw trimming and conformation data. J. Dairy Sci. 93:4883-4891. http:// dx.doi.org/10.3168/jds.2010-3183.

van der Waaij, E. H., M. Holzhauer, E. Ellen, C. Kamphuis, and G. de Jong. 2005. Genetic parameters for claw disorders in Dutch dairy cattle and correlations with conformation traits. J. Dairy Sci. 88:3672-3678.

Walker, S. L., R. F. Smith, J. E. Routly, D. N. Jones, M. J. Morris, and H. Dobson. 2008. Lameness, activity time-budgets, and estrus expression in dairy cattle. J. Dairy Sci. 91:4552-4559. http:// dx.doi.org/10.3168/jds.2008-1048.

Webster, J. 1993. Understanding the Dairy Cow. 2nd ed. Blackwell Scientific Publications, Oxford, UK. 